\title{
PRECIPITATION OF NICKEL DIHALIDE IN THERMALLY PRETREATED $\mathrm{NaCl}: \mathrm{Ni}^{2+}$ CRYSTALS
}

\author{
T. Morawska-Kowat, D. Nowak-Woźny and M. Suszyńska \\ W. Trzebialowski Institute of Low Temperature and Structure Research \\ Polish Academy of Sciences, Okólna 2, 50-950 Wroctaw, Poland
}

(Received May 17, 1994; revised version July 5, 1994)

\begin{abstract}
Optical absorption and the yicld stress value of $\mathrm{NaCl}: \mathrm{Ni}^{2+}$ crystals were measured as functions of the anncaling temperature. Morphology and possible structure ty' pes of the $\mathrm{NiCl}_{2}$ particles formed under different annealing conditions have been shortly discussed.
\end{abstract}

PACS numbers: 61.72.-y, 78.20.-e, 78.50.-w

\section{Introductory information}

It was evidenced previously [1-5] that the absorption spectra of nickel-doped $\mathrm{NaCl}$ crystals are sensitive to both the concentration and the dispersion form of the dopant. In order to obtain more details about the aggregation- and/or precipitation-related phenomena Bridgman-grown $\mathrm{NaCl}: \mathrm{Ni}^{2+}$ crystals were solution-treated, i.e. air-quenched after 30 minutes of annealing at $873 \mathrm{~K}$, and additionally annealed at temperatures ranging between room temperature (RT) and the solution treatment temperature (ST). For aim of comparison, as-received (AR) samples were also tested. The dopant concentration, equal to $160 \mathrm{ppm}$, was determined from the absorption coefficient of the main absorption band $\left(\alpha_{\mathrm{C}}\right)$ according to the method described elsewhere [6]; the ppm is expressed as the number of $\mathrm{NiCl}_{2}$ moles per $10^{6}$ moles of $\mathrm{NaCl}$. For these samples the yield stress value was critically compared with some data obtained from the optical absorption spectra. The stress/strain curves were taken at R'T by using the 1112 INSTRON machine working at the strain rate of $3 \times 10^{-1} \mathrm{~s}^{-1}$; the yield stress value $\left(\sigma_{0}\right)$ was determined at $0.1 \%$ of plastic strain. Optical absorption spectra were measured in the spectral range from $50 \times 10^{3}$ to $11 \times 10^{3} \mathrm{~cm}^{-1}$ by employing the SPECORD M-40 (Zeiss) spectrophotometer. 


\section{Results and discussion}

\subsection{Oplical absorplion}

Spectral characteristics of the detected absorption bands have been collected in Table I for as-received, solution-treated and samples additionally annealed ( $\mathrm{AA}$ ) after the solution treatment. The oscillator strength valucs $f_{i}$ were calculated according to the Smakula equation for Gaussian bands wilh the refractive index-value taken for RT [7].

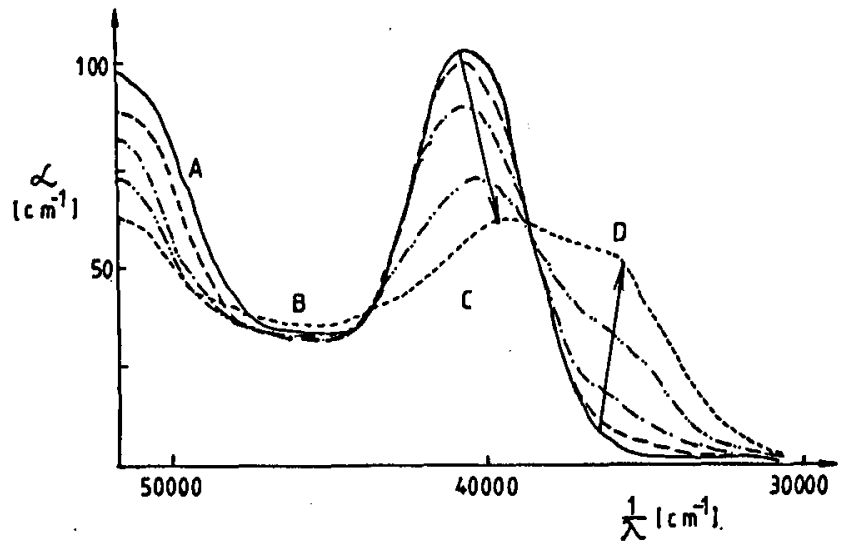

Fig. 1. Changes of the optical absorption spectra during isochronal (50 h) annealing at temperatures 323-623 $\mathrm{K}$; the arrow marks the direction of the increasing tempcrature.

TABLE I

Some characteristics of the optical absorption bands.

\begin{tabular}{l|c|c|c|c}
\hline \multicolumn{1}{c|}{$\begin{array}{c}\text { Samples } \\
\text { Quantity }\end{array}$} & AR & ST & $323 \mathrm{~K}$ & $473 \mathrm{~K}$ \\
\hline$\lambda(\mathrm{A})[\mathrm{nm}]$ & 193 & 200 & 197 & 200 \\
$\alpha(A)\left[\mathrm{cm}^{-1}\right]$ & 80 & 82 & 82 & 35 \\
$f(\mathrm{~A})$ & 0.12 & 0.14 & 0.13 & 0.16 \\
\hline$\lambda(B)[\mathrm{mm}]$ & 216 & - & 216 & 216 \\
$\alpha(B)\left[\mathrm{cm}^{-1}\right]$ & 29 & - & 30 & 28 \\
$f(B)$ & 0.02 & - & 0.02 & 0.01 \\
\hline$\lambda(\mathrm{C})\left[\mathrm{nm}^{-1}\right.$ & 242 & 248 & 242 & 252 \\
$\alpha(\mathrm{C})\left[\mathrm{cm}^{-1}\right]$ & 116 & 100 & 108 & 50 \\
$f(\mathrm{C})$ & 0.15 & 0.14 & 0.15 & 0.03 \\
\hline$\lambda(\mathrm{D})[\mathrm{nm}]$ & - & - & - & 276 \\
$\alpha(D)\left[\mathrm{cm}^{-1}\right]$ & - & - & - & 49 \\
$f(D)$ & - & - & - & 0.07
\end{tabular}


Figure 1 presents the absorption spectra of ST-samples isochronally annealed $(50 \mathrm{~h})$ at temperatures between 323 and $623 \mathrm{~K}$. Especially interesting are the results obtained for ST-samples additionally annealed at temperatures above $473 \mathrm{~K}$. While the AR- and ST-spectra consist of three $(A, B, C)$ and two $(A, C)$ strong bands, respectively, the AA-spectra exhibit the presence of an additional band (D) located at about $276 \mathrm{~nm}$. The absorption cocfficient of this band $\left(\alpha_{D}\right)$ increases during the annealing and this increase is accompanied by the decrease in $\alpha_{\mathrm{C}}$ characteristic of band C. It secms reasonable to assume that the centres related to D-type optical transitions appear at the expenses of centres related to the characteristic C-type absorption.

\section{2. $0.1 \%$ proof slress}

Figure 2 shows the effect of annealing time at different annealing temperatures upon the yield stress value of $A A$-crystals $\left(\sigma_{0}(t)\right)$ with respect to the ST-ones $\left(\sigma_{0}(\mathrm{ST})\right)$; the annealing temperature was chosen from the range between $\mathrm{RT}$ and $673 \mathrm{~K}$. It has been stated that the value of $\Delta \sigma_{0}=\sigma_{0}(l)-\sigma_{0}(\mathrm{ST})$ is positive for AA-samples annealed at temperatures between R' and $473 \mathrm{~K}$; for higher annealing temperatures $\Delta \sigma_{0}=0$.

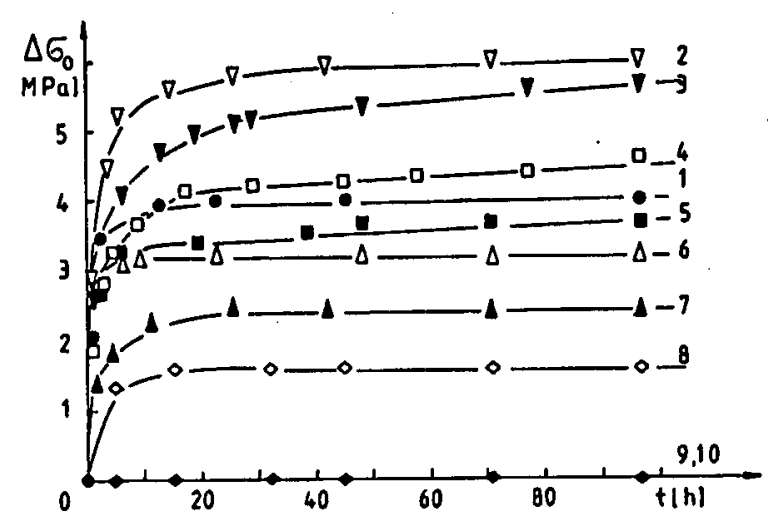

Fig. 2. Yield stress changes $\left(\Delta \sigma_{0}(l)=\sigma_{0}(t)-\sigma_{0}(\mathrm{ST})\right)$ induced by annealing at $323(1)$, $333(2), 343(3), 353(1), 373(5), 403(6), 433(7), 463(8), 473(9)$ and $523 \mathrm{~K}(10)$.

The optical $\left(\alpha_{\mathrm{C}}, \alpha_{\mathrm{D}}\right)$ and mechanical $\left(\Delta \sigma_{0}\right)$ characteristics of isochronally annealed samples have been compared in Fig. 3. Although the yield stress value of samples annealed at high temperatures (at and above $473 \mathrm{~K}$ ) is equal to the value characteristic of ST specimens $\left(\Delta \sigma_{0}=0\right)$, the absorption spectra of both kinds of crystals differ from each othcr. Thus, the relative softening of $A A$-samples cannot be related to thermal decomposition of the obstacles effective after annealing at low tempcratures; these obstacles are related to $\mathrm{NiCl}_{2}$ particles formed in $\mathrm{NaCl}$ crystals at about $323 \mathrm{~K}$ [2]. The effect of the high temperature annealing is explainable in terms of a $\mathrm{NiCl}_{2} \Rightarrow \mathrm{NiCl}_{2}^{*}$ transformation, where the $\mathrm{NiCl}_{2}^{*}$ particles could be considered as the "vacancy-riclı" $\mathrm{NiCl}_{2}$ phase suggested by Andreev at al. [8]. 


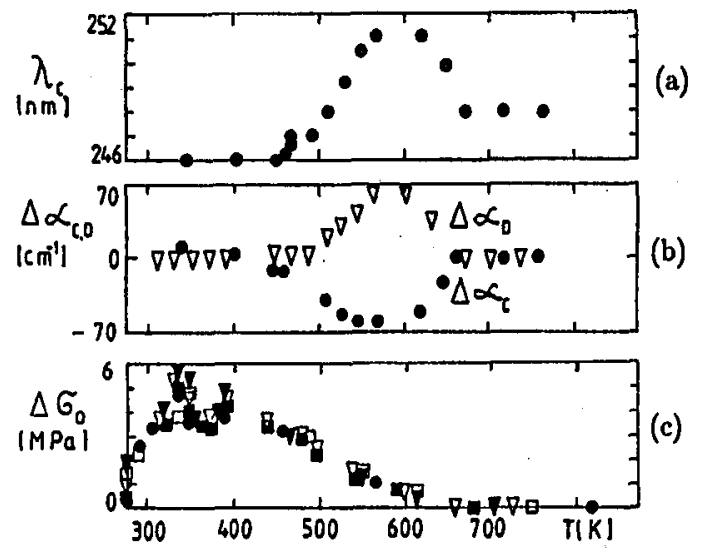

Fig. 3. The isochronal $(50 \mathrm{~h})$ dependences of the C-band position (a), of the changes of absorption coefficients of bands C and D (b), and of the yield stress changes (c).

\subsection{Precipilation-relaled phenomena}

Some aspects of the precipitation of nickel dilialide phases were investigated by using an Avrami-type equation in which the fraction of the dopant transformed into precipitated particles $(p)$ was determined in the way previously proposed for $\mathrm{NaCl}: \mathrm{Eu}^{2+}$ crystals [9].

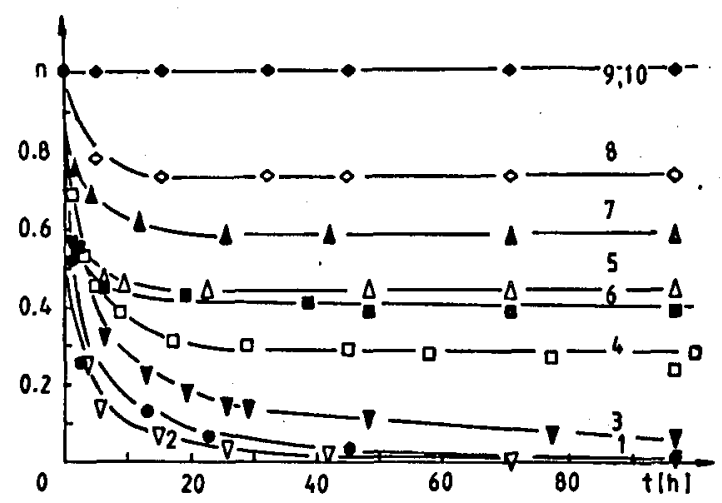

Fig. 4. Time dependences of the unprecipitated fraction of the dopant (n) during annealing at 323 (1), 333 (2), 343 (3), 353 (4), 373 (5), 403 (6), 433 (7), $463(8), 473$ (9) and $523 \mathrm{~K}(10)$; the data are representative of the absorption coefficient of the main absorption band.

Figures 4 and 5 show the isothermal $n$-values $(n=1-p)$ determined from the optical and mechanical data, respectively, and Table II collects values of the Avrami parameter $m$ [10]. According to the precipitation models [11, 12], the precipitation rate below $403 \mathrm{~K}$, where $m<1$, should be driven by a dislocation-aided 


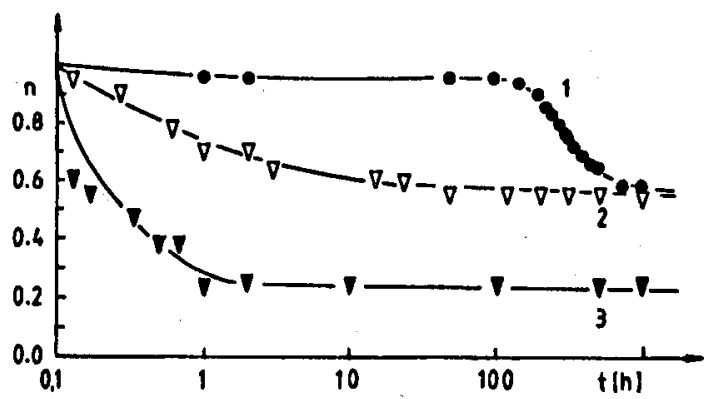

Fig. 5. Time dependences of $n$ during annealing at 473 (1), 573 (2) and $623 \mathrm{~K}$ (3); these data are representative of the yicld stress measurements.

TABLE II

Values of the Avrami parameter $m$.

\begin{tabular}{c|l}
\hline \hline T $[\mathrm{K}]$ & $m$ \\
\hline 283 & 0.1 \\
323 & 0.1 \\
333 & 0.3 \\
353 & 0.4 \\
363 & 0.7 \\
373 & 0.8 \\
433 & 1.5 \\
474 & 2.0 \\
573 & 1.5 \\
623 & 1.5
\end{tabular}

process, whereas above this temperature bulk diffusion and processes at the particle/matrix interface should be dominant $(m=1.5 \div 2.0)$. This means that the strengthening effect is characteristic of this annealing temperature range for which $m<1$, whereas $m>1$ correlates with $\Delta \sigma_{0}=0$.

\subsection{Structure of the $\mathrm{NiCl}_{2}^{*}$ phase}

In order to explain the correlations betwcen precipitation and strengthening phenomena let us assume that both nickel dihalide particles formed under different annealing conditions are of the same geometrical shape. In terms of the considered precipitation models $[11,12]$, they should be rods oriented along $\langle 110\rangle$ direction. In fact, this shape was confirmed experimentally by some microscopic observations $[13,14]$.

If so, the high temperature phase should have the same crystallographic structure as the low temperature one, i.e. the hexagonal unit cell of the $\mathrm{CdCl}_{2}$-type. 
Because of some differences in the density of $\mathrm{NaCl}$ crystals containing either $\mathrm{NiCl}_{2}$ or $\mathrm{NiCl}_{2}^{*}$, considered as equivalent to the "vacancy-rich" $\mathrm{NiCl}_{2}$ pliase [8], one has to expect that the lattice parameter $h^{*}$ of the ligh temperature pliase is slightly larger than $h$ characleristic of the low temperature $\mathrm{NiCl}_{2}$.

In order to estimate the $h^{*}$-value, the elementary cell of $\mathrm{NiCl}_{2}$ was matched with that of $\mathrm{NaCl}$. It was assumed that the sixfold rotation axis of the $\mathrm{NiCl}_{2}$ elementary cell is parallel to the shortest slip vector of the matrix, $d_{(110)}$. A matching parameter was estimated on the basis of the following relation:

$$
\varepsilon=\left(n^{*}-n\right) / d_{\langle 110\rangle}
$$

where $n^{*}=h n_{\text {hex }} / d_{(110)}, n$ is the cntirc part of $n^{*}$ and $n_{\text {hex }}$ is the number of hexagonal $\mathrm{NiCl}_{2}$ cells along the $\langle 110\rangle$ dircction. This parameter described the misfit parameter for a group of $n_{\text {hex }} \mathrm{NiCl}_{2}$ elementary cells.

The smallest value of $\varepsilon(0.04)$ was obtained for a group of $7 \mathrm{NiCl}_{2}$ cells. On assuming that the $\varepsilon$ parameter for 7 cells of the high temperature phase is equal to zero, the new parameter of $h^{*}$ equals $17.38 \AA$.

\section{Summaxy}

In additionally anncaled solution-treated $\mathrm{NaCl}: \mathrm{Ni}^{2+}$ crystals the dopant is precipitated in two forms of the nickel dihalide. Both phases are hexagonal with a slightly different lattice parameter " $h$ ". The transformation occurs at temperatures equal and higher than $473 \mathrm{~K}$ and involves the decrease in crystal density.

This work has been done in frames of the project No. 2 P302 17804 of the Committee for Scientific Research.

\section{References}

[1] K. Polak, Z. Plyys. 223, 338 (1969).

[2] D. Nowak-Woźny, M. Suszyirska, Acla Phys. Pol. A 81, 119 (1992).

[3] M. Suszyńska, Scicnce Forum 126-128, 119 (1993).

[1] M. Suszyniska, R. Capellctti, Malcr. Chem. Phys. 34, 228 (1993).

[5] D. Nowak-Woźny, M. Suszyúska, M. Szmicla, R. Capelletti, J. Maler. Sci. 28, 645 (1993).

[6] D. Nowak-Woźny, PhD Thesis, Inst. of Low Temperature and Structure Research, Polish Acadcmy of Scicnces, Wrockaw 1994.

[7] The Physicochemical IIandbook, Eds. J. Gajewska, S. Pietras, J. Rudziniska, A. Schellenberg, PWN, Warszawa 1974 (in Polish).

[8] A. Andreev, M. Ilartmanova, V.A. Kilimov, Phys. Slalus Solidi A 41, 697 (1977).

[9] D. Nowak-Woźuy, Cryst. Res. Technol. 24, 979 (1989).

[10] M. Avrami, J. Chem. Physs. 0, 177 (1941).

[11] C. Zener, Trans. A.I.M.E. 167, 550 (1946).

[12] C. Wert, J. Appl. Phys. 20, 943 (1949).

[13] A. Andreev, M. IIartmanova, V.A. Klimov, Phys. Slalus Solidi A 62, 35 (1980).

[14] M. Szmida, private communications. 